\title{
Bibliografi över judaistisk forskning i Norden 1986-1988/ Bibliography of Jewish studies in Scandinavia 1986-1988
}

\author{
Björn Dahla and Nils Martola
}

Åbo

[Bibliografin sammanställdes av FM Björn Dahla inom ramen för den bibliografiska verksamhet som bedrivs i Donnerska institutet för religionshistorisk och kulturhistorisk forskning i Åbo. TD Nils Martola kompletterade bibliografin och genomförde klassifikationen i enlighet med det klassifikationssystem som används i Institutum Judaicum Aboense, och vilken är en tillämpning av David H. Elazar \& Daniel J. Elazars A classification system for libraries of Judaica (2 uppl. 1979).]

[The bibliography was compiled by FM Björn Dahla in the course of the bibliographical activity carried on in the Donner Institute for Research in Religious and Cultural History in Åbo. TD Nils Martola completed the bibliography, and carried through the classification in accordance with the system used in Institutum Judaicum Aboense, and which is an application of David H. Elazar \& Daniel J. Elazar's A classification system for libraries of Judaica (2nd ed. 1979).]

Förkortningar/Abbreviations

Amol Det var engang ... amol iz geven ...jødisk kultur i det gamle Østeuropa. Eds. Helen Krag, Margit Warburg. København 1986.

JuK Judendom och kristendom under de första århundradena : nordiskt patristikerprojekt 1982-1985

JuN Judiskt liv i Norden. Eds. Gunnar Broberg, Harald Runblom, Mattias Tydén. Uppsala 1988. (Acta universitatis upsaliensis. Studia multiethnica upsaliensia 6). Summaries in English.

NJ Nordisk judaistik/Scandinavian Jewish Studies

RelD Religionsunterricht und Dialog zwischen Judentum und Christentum. Eds. R.E. Heinonen, K.-J. Illman, A. Toivanen. Åbo 1988. 


\section{Bible commentaries-classic}

\section{Kronholm, Tryggve}

Toratexter och targumtolkningar : några tankar kring Roger Syréns doktorsavhandling "The blessings in the Targums". [Torah texts and Targum interpretation : some thoughts on Roger Syrén's dissertation "The blessings in the Targums]. $N J, 8(1) 1987,37-49$.

\section{SYRÉN, Roger}

The blessings of the Targums : a study on the Targumic interpretations of Genesis 49 and Deuteronomy 33. Åbo : Åbo Akademi, 1986. 259 pp. (Acta Academiae Aboensis. Ser. A. Humaniora 64,1). Diss.

\subsection{History of biblical translations}

\section{Beskow, Per}

Hieronymus och judarna. [Hieronymus and the Jews]. JuK II. Oslo 1986, 243-253.

\section{Kruse-Blinkenberg, Lars}

Dansk-jødisk sprogbrug : tre forsøg. [Danish-Jewish language usage : three attempts]. København : Reitzel, 1986. 142 pp. (Skrifter udgivet af Københavns Universitets institut for religionshistorie 7).

SYRÉN, Roger

Vad är "targum"? [What is "targum"?] Teologisk tidskrift, 91 1986, 474-477.

\section{Biblical institutions and society}

\section{Hultgård, Anders}

The burnt-offering in early Jewish religion : sources, practices and purpose. Gifts to the gods : proceedings of the Uppsala Symposium 1985. Eds. Tullia Linders and Gullög Nordquist. Uppsala 1987, 83-91. (Boreas 15).

\section{Biblical biography}

\section{LARSSON, Göran}

Jakob. 2. Judentum. Theologische Realenzyklpädie (TRE), 16 1987, 466-468

\subsection{Dead Sea scrolls}

\section{Mink, Hans-Aage}

The use of Scripture in the Temple Scroll and the status of the scroll as law. Scandinavian journal of the Old Testament, 1 1987,
20-50.

\section{Contents of the Torah}

\section{Veijola, Timo}

Thora als Inhalt der Lehre in der deuteronomistischen Literatur : Korreferat zum Vortrag von Klaus-Dietrich Schunck "Thora als Unterweisung”. RelD, 98-106.

\section{Esther}

\section{RÄISÄNEN, Heikki}

Komedia antisemitismin alkuajoilta : Esterin kirja kaunokirjallisena luomuksena. [A comedy from the beginnings of anti-Semitism : the book of Esther as a literary product]. Teologinen aikakauskirja, 92 1987, 210-215.

\section{Apocrypha}

\section{Enermalm-Ogawa, Agneta}

Un langage de priere Juif en Grec : le témoignage des deux premiers livres des Maccabées. Stockholm : Almqvist \& Wiksell Int., 1987. 157 pp. (Coniectanea Biblica. New Testament series 17$)$.

see 136: JENSEN

\section{Pseudepigrapha}

Hartman, Lars

Vad säger Sibyllan? : byggnad och budskap i de sibyllinska oraklens fjärde bok. [What does the Sibyl say? : structure and message of the fourth book of the Sibylline Oracles]. Context : festskrift till Peder Johan Borgen. Eds. P.W. Beckman, R.E. Kristiansen. Trondheim 1987, 61-74. (Relieff 24).

see 136: JENSEN

\section{Mishna, works on}

Martola, Nils

Litterära former i Mishna. [Literary forms in Mishna]. $N J, 8(2)$ 1987, 106-148.

\section{Jewish theological and theosophic concepts}

HULTG \& RD, Anders

Eskatologin i den intertestamentala perioden. [Jewish eschatology in the period between the testaments]. JuK I. Oslo 1986, 85-97. 
JENSEN, Hans J. Lundager

Die Pervertierung der Küche und die Dialektik der Aufklärung : eine strukturell-exegetische Meditation über das Martyrium der Juden im 2. und 4. Makkabäerbuch. Temenos, 39-54.

\section{JEPPESEN, Knud}

Den nye pagt $i$ Det gamle Testamente og den antike jødedom. [The new covenant in the Old Testament and ancient Judaism]. $J u K I$. Oslo 1986, 68-84.

Martola, Nils

Partikularism och universalism i diasporajudendomen. [Particularism and universalism in diaspora Judaism]. JuK II. Oslo 1986, $49-64$.

\section{Müller, Mogens}

Messias og "menneskesønnen" i den intertestamentale periode. [Messiah and "the Son of Man" in the intertestamental period]. JuK $I$. Oslo 1986, 98-111.

NiELSEN, Eduard

Udvælgelse og universalisme i Det gamle Testamente. [Chosenness and universalism in the Old Testament]. JuK I. Oslo 1986, 52-67.

SANDELIN, Karl-Gustav

Wisdom as nourisher : a study of an Old Testament theme : its development within early Judaism and its impact on early Christianity. Åbo: Åbo Akademi, 1986. 274 pp. (Acta academiae Aboensis. Ser. A. Humanistiska vetenskaper 64,3).

SANDELIN, Karl-Gustav

Vishetens måltid. [The meal of wisdom]. JuK I. Oslo 1986, 268-283.

Vasko, Timo

Onko juutalaisuudessa systemaattista teologiaa? [Is there a systematic theology in Judaism?]. Teologinen aikakauskirja, 91(2) 1986, 102-105.

see 019: VeIJOLA

see 173: TARKKI

see 670: WEINHOLT

\section{Aggadah, classical midrash}

HobBel, Arne J.

Hva er midrasj?[What is Midrash?] $N J$, 7(2) 1986, 57-70.

\section{Kabbalah}

WINTHER, Judith

Kabbalah : en rejse i jødisk mystik. [Kabbalah : a journey in Jewish mysticism]. Lynge : Forlaget Bogan, 1986. 150 pp.

WinTHER, Judith

Religion, tradition og jødisk mystik. [Religion, tradition and Jewish mysticism]. Chaos, 9 1988, 80-101.

see 951: BoLL

\section{Modern kabbalah}

WINTHER, Judith

Rabbi Avraham Yizhak HaCohen Kook : between exile and messianic redemption. $N J$, 9(2) 1988, 69-81.

\section{Non-Jewish kabbalistic adaptations}

\section{Giversen, Søren}

Gnostisk skriftforståelse. [Gnostic understanding of Scripture]. JuK II. Oslo 1986, 7792.

\section{Hellenistic Jewish thought}

Hultg åd, Anders

Mages zoroastriens et prètres juifs : influences religieuses à l'époque hellénistique. Revue d'histoire et de philosophie religieuses, 68 1988, 415-428.

see 661: VILLADSEN

See 727: BEKKEN, BORGEN

\section{Maimonides}

TARKKI, Jarmo

Maimonides ja jumala. [Maimonides and God]. Teologisk tidskrift, 91 1986, 598-605.

\section{Modern Jewish thought}

DenCIK, Lars

Ett judiskt förhållningssätt. [A Jewish attitude]. Vår lösen, 79(6) 1988, 398-404.

Wigen, Tore

Moderne jødisk religionsfilosofi. [Modern Jewish philosophy of religion]. Tidsskrift for teologi og kirke, 59(1) 1988, 45-62. 


\section{Jewish Existentialism}

\section{Benktson, Benkt-Erik}

Färgblivandets under och det stora Duet : framåtpekande drag i den så kallade fördialogiska fasen av Martin Bubers tänkande. [The wonder of colouring and the great Thou : forward pointing items in the so-called predialogical level of Martin Buber's thinking]. $N J, 9(1)$ 1988, 1-20.

\section{Oriental Jewish folklore}

\section{Asmussen, Jes P.}

Ein Bruchstück aus Jehuda Lari's jüdischpersischem Weisheitsbuch Machzan alpand, "Schatzkammer der Belehrung". Cahiers Ferdinand de Saussure 41. Genève 1987, 21-26.

\section{Laws (halakot), customs and ceremonies}

Gunder-Hansen, Edwin \& Melchior, Bent Jødiske ritualbade. [Jewish ritual bath]. Sfinx 10 (4) 1987, 135-139.

\section{Jewish liturgy}

see 727: BEKKEN

\section{Pesah (Passover)}

Martola, Nils

Kommentar till Påskhaggadan. [A commentary to the Passover Haggadah] . Åbo : Åbo Akademi, 1988. 150pp. (Religionsvetenskapliga skrifter. 16)

\section{History of Jewish education}

\section{WARBURG, Margit}

Krop og kultur : i det jødiske Østeuropa. [Body and culture : in the Jewish Eastern Europe]. Religion og opdragelse : laereprocesser $i$ fremmede kulturer. Eds. K. Rendtorff, M. Sundby. Viby 1987, 24-37.

\section{Elementary and intermediate education- methodology and materials}

BorgEGARD, Gunnel

Exempel på undervisning om judendom i Sverige. [Examples of the teaching of Judaism in Sweden]. NJ, 7(1) 1986, 29-34.

\section{Christensen, Merete}

Undervisning i jødedommen i Danmark : kristendom på barnestadiet eller myndigt individ. [Teaching of Judaism in Denmark : Christianity in its childhood or an individual come of age?] $N J, 7(1) 1986,42-46$.

Heinonen, Reijo [E.]

Torakunskapen i kristen religionsundervisning : ett försök till didaktiskt korrektiv ur ekumenisk synvinkel. [Knowledge of torah in Christian religious education]. $N J, 7(2), 1986$, 104-112

\section{ILLMAN, Karl-Johan}

Altes Testament und Judentum in den schwedischsprachigen Religionsbüchern für die Grundschule in Finnland. RelD, 117-140.

ILlMAN, Karl-Johan

Judar och judendom i kristen skolundervisning. [Jews and Judaism in Christian school teaching]. $N J, 7(1) 1986,1-6$.

ILLMAN, Karl-Johan

Några centrala judiska begrepp i de finlandssvenska religionsböckerna for grundskolan. [Some central Jewish concepts in Swedish language school books in Finland on the subject of religion]. $N J, 7(1) 1986,7-20$.

\section{WAHLSTROM, Bertel}

Bilden av judar och judendomen i gymnasiets religionsundervisning i Finland. [The picture of Jews and Judaism in the religious instruction in the upper school (Gymnasium) in Finland]. $N J, 7(1)$ 1986, 21-28.

VirTanen, Teuvo

Judendomen i det kursbundna gymnasiets läroböcker. [Judaism in high school books in Finland]. $N J, 7(1)$ 1986, 29-34.

\section{Yiddish}

KATlEV, Jan

Jiddisch. Amol, 93-110

\section{Judaeo-Persian}

see 191: Asmussen 
500.7 Jewish literature-history and development/Humor, satire, wit

TOGeBY, Ole 190

Jødisk vid. [Jewish humor]. Amol, 171-

\section{Jewish literature: criticism and analysis}

Ahokas, Pirjo

Jewish/Christian symbolism in Bernard Malamud's novel "God's grace". $N J, 7(2) 1986$, 84-91.

\section{BLOM, Anton}

Elie Wiesel og ansiktet $i$ vinduet. [Elie Wiesel and the face in the window]. Oslo : Cappelens, 1987. 237 pp.

Frank, Margit

Das Bild des Juden in der deutschen Literatur im Wandel der Zeitgeschichte : Studien zu jüdischen Gestalten und Namen in deutschsprachigen Romanen und Erzählungen 19181945. Freiburg : Burg-Verlag, 1987. 303 pp. (Hochschulproduktionen. Germanistik. Linguistik. Literaturwissenschaft 9).

Frank, Margit

Om Elias Canetti. $N J, 9(1)$ 1988, 21-31

Høst Heyerdahl, Gerd

Glimt fra Elie Wiesels forfatterskap.

[Glimpses from Elie Wiesel's literary production]. $N J, 9(2)$ 1988, 92-98.

ILLMAN, Karl-Johan

Litteratur om och av Elie Wiesel. [Literature about and by Elie Wiesel]. $N J, 9(2) 1988$, 82-91.

JoNsson, Inge

Bibeln i literaturen. [The Bible in literature]. $N J, 8(1) 1987,18-27$.

ÅsBerg, Christer

Bibeln som literatur. [The Bible as literature]. $N J, 8(1) 1987,1-17$.

\section{Migrations}

see 769: BlüDNIKow, Burstein, Johansen

\section{Women's position and treatment}

BÉLINKI, Karmela

Biblical women : Jewish literary and religious ideals. $N J, 8(2) 1987,149-158$.

\section{Goldman, Anita}

Vära bibliska mödrar. [Our Biblical mothers]. Stockholm : Natur och kultur, 1988. 138 pp.

640.3 Educational institutions and organizations./Libraries and archives

Almbladh, Karin

C. Vilh. Jacobowskys Judaicasamling.

[The Judaica collection of C. Vilh. Jacobowsky]. $N J, 8(2)$ 1987, 158-166.

\section{Jewish identity}

\section{ILICKI, Julian}

Den föränderliga identiteten : om identitetsförändringar hos den yngre generationen polska judar som invandrade till Sverige under åren 1968-1972 : en rapport från forskningsprojektet "Judisk identitet-förändringar i samband med migration. [The changeable identity : on changing identity among the younger generation of Polish Jews immigrating to Sweden in 1968-1972]. Åbo: Sällskapet for judaistisk forskning, 1988. $371 \mathrm{pp}$. (Skrifter utgivna av sällskapet för judaistisk forskning 7).

\section{ILICKI, Julian}

Identitetsförändringar hos yngre polska judar i Sverige efter 1968. [Identity transformation among Polish Jews in Sweden after 1968]. JuN, 329-350.

\section{SchaTZ, Jaff}

At the end of the road : the ethnic identity of the former Jewish Communists of Poland. $N J, 9(1)$ 1988, 32-50

WARBURG, Margit

Jødisk dagligliv og selvforståelse. [Jewish daily life and self-understanding]. Amol, 129149.

661 General relations between Jews and nonJews

Beltzikoff, Boris

Boken om Job. Svensk kyrkotidning, 82 1986, 175-177. 


\section{BELTzIKoFf, Boris}

Mina möten med kristendomen. [My encounters with Christianity]. Svensk kyrkotidning, 83 1987, 165-169.180-182.

\section{Beskow, Per}

Judendom och kristendom i de östliga provinserna under det tredje århundradet. [Judaism and Christianity in the Eastern provinces during the third century]. JuK II. Oslo 1986, 125-132.

\section{Edsman, Carl-Martin}

Det jude-kristna problemet. [Das jüdischchristliche Problem]. Svensk Missionstidskrift, 75(4) 1987, 51-55.

ForNBERG, Tord

Jewish-Christian dialogue and biblical exegesis. Uppsala : Uppsala universitet, 1988. 74 pp. (Studia missionalia Upsaliensia 47).

Gerhardsson, Birger

Jesus och Torah. [Jesus and the Torah]. JuK I. Oslo 1986, 124-144.

HeInonen, Reijo E.

Ökumenischer Denkprozess und der Dialog zwischen Christentum und Judentum : ein Beitrag zur Didaktik des ökumenischen Lernens. RelD, 141-159.

HIdAL, Sten

Den antiokenska exegetikskolan och judisk skriftlärdom. [The Antioch school of exegesis and Jewish biblical scholarship]. JuK II. Oslo 1986, 190-200.

\section{HäLLSTROM, Gunnar af}

Celsus och Origenes syn på förhållandet mellan judendom och kristendom. [Celsus' and Origen's view of the relationship between Judaism and Christianity]. JuK II. Oslo 1986, 113-124.

\section{ILLMAN, Karl-Johan}

Judisk-kristen dialog på det akademiska området. [Jewish-Christian dialogue on an academic level]. JuK I. Oslo 1986, 13-36.

ILLMAN, Karl-Johan

Vägar till judisk-kristen dialog. [Ways to a Jewish-Christian dialogue]. Theologia et cultura : studia in honorem Gotthard Nygren.

Eds. Fredric Cleve, Hans-Olof Kvist. Åbo 1986 , 31-42. (Meddelanden från Stiftelsens för Åbo Akademi forskningsinstitut 112).

\section{KRONHOLM, Tryggve}

Jesus och de kristna i rabbinsk tradition. [Jesus and the Christians in Rabbinic tradition]. JuK I. Oslo 1986, 284-308.

\section{Kronholm, Tryggve}

Mångfald, trefald och faran för kyrklig enfald : några tankar om judendomen, kristendomen och islam. [Some thoughts on Judaism, Christianity, and Islam]. Svensk teologisk kvartalskrift, 64 1988, 93-101.

KUPCZYK-LEWIN, Lola

Symposium i Oxford 17-21 september 1984 om relationer mellem jøder og polakker i moderne historie. [A symposium in Oxford in September 17-21, 1984, on the relations between Jews and Poles in modern history]. $N J$, 7 (2) 1986, 113-119

Kvarme, Ole Chr. M.

Jødekristendommen-fiksjon eller historisk realitet? [Jewish Christianity-fiction or historical reality?]. $J u K I I$. Oslo 1986, 13-35.

LARSSON, Edvin

Hellenisterna och urforsamlingen. [The Hellenists and the first congregation]. JuK $I$. Oslo 1986, 145-164.

LehmanN, Henning

Den jødiske hellige skrift og jødiske tradisjoner hos en kristen syrisk forfatter i 4 . årh. [Jewish sacred scripture and Jewish traditions in a Syrian Christian author of the 4th century]. JuK II. Oslo 1986, 220-228.

\section{LEIVESTAD, Ragnar}

Hvem ville Jesus være? [Who did Jesus want to be?]. JuK I. Oslo 1986, 112-123.

Levy, Anne Marie Lund

Kirke og jøder i Sør-Europa. [The Church and the Jews in Southern Europe]. Kirke og kultur, 92 1987, 507-512.

LINDESKOG, Gōsta

Das jüdisch-christliche Problem : Randglossen zu einer Forschungsepoche. Uppsala : Uppsala universitet, 1986. 241 pp. (Acta universitatis upsaliensis. Historia religionum 9).

LOVESTAM, Evald

Urkyrkans skriftforståelse. [The understanding of the Scriptures in the early Church]. $J u K I$. Oslo 1986, 259-267. 


\section{Montgomery, Hugo}

Kampen mellan judendom och kristendom i de latinska provinserna under 200-talet. [The struggle between Judaism and Christianity in the Latin provinces in the 3rd century]. $J u K I I$. Oslo 1986, 133-146.

\section{MülLER, Mogens}

Jødedommens Bibel på nytestamentlig tid og den kristne Bibel : Hebraica sive Graeca veritas? [The Jewish Bible in New Testament times and the Christian Bible]. Dansk teologisk Tidsskrift, 51(3) 1988, 220-237.

NaRrowe, Morton $\mathrm{H}$.

En jude ser på stilla veckan. [A Jew looks at Holy Week]. Var lösen, 79(2) 1988, 111115.

\section{Noack, Bent}

Den nye pagt i Det nye Testament. [The new covenant in the New Testament]. JuK I. Oslo 1986, 237-258.

Olsson, Birger

Den petrinska traditionen och judarna. [Petrine tradition and the Jews]. JuK I. Oslo 1986, 215-236.

Pedersen, Michael Bjørn

Jøde eller hedning? : Efeserbrevets forfatter. [Jew or heathen? : the author of the Letter to the Ephesians]. Dansk teologisk Tidsskrift, 51(4) 1988, 277-288.

Ringgren, Helmer

Dialogen mellan kristendom och judendom $i$ ett historiskt perspektiv. [The dialogue between Christianity and Judaism in a historical perspective]. JuK II. Oslo 1986, 273-280.

\section{RÄISÃNEN, Heikki}

Kuvamme Jeesuksesta ja juutalaisuudesta : kaksi projektiota. [Our picture of Jesus and of Judaism : two projections]. Kristillinen kasvatus, 2 1986, 18-23, 27.

RÄISÃNEN, Heikki

Pauli brytning med Israels förbund.

[Paul's break with the covenant of Israel]. $N J$, 8 1987, 28-36.

\section{RÄISANEN, Heikki}

The Torah and Christ : essays in German and English on the problem of the law in early Christianity. Hki : Suomen eksegeettinen seura, 1986. 377 pp. (Suomen eksegeettisen seuran julkaisuja 45).

\section{SAARINEN, Risto}

Wandlungen des Lutherbildes zwischen Liberalismus und Antisemitismus : zum Verhältnis von Judentum und Luthertum bei Hermann Cohen und Erich Vogelsang. RelD, 2743.

Seland, Torrey

Jødene og kristendomsforfølgelsene. [Jews and the persecution of Christians]. JuK II. Oslo 1986, 147-172.

Skarsaune, Oskar

Jødisk-kristen dialog på ekumenisk område-en orientering. [Jewish-Christian dialogue on an ecumenical basis-an orientation]. JuK I. Oslo 1986, 37-51.

Skarsaune, Oskar

Oldkirkens kristologi og de jødiske frelsesforventningene. [Christology of the early church and the Jewish expectations of salvation]. JuK II. Oslo 1986, 201-219.

THURÉn, Jukka

Paulus och Torah. [Paul and the Torah]. JuK I. Oslo 1986, 165-192.

Trautner-Kromann, Hanne

Jewish polemics against Christianity and the Christians in Northern and Southern France from 1100 to $1300 . N J, 7(2) 1986,71-83$.

VASKo, Timo

Das christliche Zeugnis unter den Juden im 20. Jahrhundert. Mission : erfahren, gepredigt, reflektiert : Prof. Dr. Niels Peter Moritzen zum 60. Geburtstag. Eds. Friedrich Huber, Paul Freiherr von Tucher. Erlangen 1988, 68-125.

VILLADSEN, Holger

Philon og den oldkirkelige skriftfortolkning. [Philo and the early church's interpretation of Scripture]. JuK II. Oslo 1986, 93-112. WisløfF, Carl Fr.

Augustin og Det gamle testamente. [St. Augustine and the the Old Testament]. JuK II. Oslo 1986, 254-272.

see 003: Beskow 
662

Anti-Semitism

Beltzikoff, Boris

En bestseller. [om Otto

Weiningers"Geschlecht und Charakter", 1903].

Svensk kyrkotidning, 82 1986, 554-555

HaNsSON, Svante

Antisemitisk närradio : en granskning av Radio Islam.[Anti-Semitic local radio : a study of Radio Islam]. Göteborg : MH Publishing, 1988. $117 \mathrm{pp}$.

JoHANNESSON, Lena

"Schene Rariteten." : antisemitisk bildagitation i svensk rabulistpress 1845-1860. ["Schene Rariteten" : anti-Semitism in the Swedish rabid radical press, $1845-1860] . J u N$, 179-208.

Pedersen, Sigfred

Antijudaisme og antisemitisme $i$ evangelierne? [Anti-Judaism and anti-Semitism in the Gospels?]. JuK I. Oslo 1986, 193-214.

TAMM, Ditlev

Kejserdømmets antijødiske lovgivning $\mathrm{i}$ det 4. århundrede. [The Roman Empire's antiJewish laws in the 4th century]. JuK II. Oslo 1986, 173-189.

TYDÉN, Mattias

Antisemitism i Sverige 1880-1930. [AntiSemitism in Sweden, 1880-1930]. JuN, 259285.

TYDÉn, Mattias

Svensk antisemitism 1880-1930. [Anti-Semitism in Sweden, 1880-1930]. Uppsala : Centre for Multiethnic Research, 1986.83 pp. (Uppsala multiethnic papers 8 )

see 064: RAISANEN

see 769: HANSSON

see 804: HANSSON

\section{Jewish graphic and plastic art}

\section{WEINHOLT, Karin}

Om den rabbinske tolkning af billedforbudet : et bidrag til diskussionen om den billedlige kunst $\mathrm{i}$ antik jødedom og kristendom. [The Rabbinic interpretation of the picture prohibition : a contribution to the discussion of the image-like art in ancient Judaism and Christianity]. JuK II. Oslo 1986, 229-242.

\section{Synagogue architecture}

Frosell, P. Hampton

Københavns synagoger gennem tre hundrede $a$. [The synagogues of Copenhagen over a three hundred year period]. København : Reitzel, 1987. 57 pp.

\section{Jewish history}

Illman, Karl-Johan \& HaRviaInen, Tapani

Judisk historia. [A history of the Jews]. Åbo : Åbo Akademi, 1986. 145 pp. (Religionsvetenskapliga skrifter 14).

\section{Historiography}

see:727 BILDE

\section{The Jews under the Roman Empire}

Bekken, Per Jarle

Apropos jødedommens mangfold i det første århundre : observasjoner til debatten om jødisk kultus hos Filo, i Acta og Johannesevangeliet. [Concerning the plurality of Judaism during the first century : thoughts on the debate of the Jewish cult in Filon, in Acts and in the Gospel of John]. Tidskrift for teologi og kirke, 59(3) 1988, 161-173.

BILde, Per

Flavius Josephus between Jerusalem and Rome : his life, his works, and their importance. Sheffield : Sheffield Academic Press, 1988. 240pp. (Journal for the study of the pseudepigrapha. Supplement series. 2)

Bilde, Per

Main trends in modern Josephus research. NJ, 8(2) 1987, 73-105.

Borgen, Peder

Philo, John and Paul : new perspectives on Judaism and early Christianity. Atlanta, GA : Scholars Press, 1987. 324 s. (Brown Judaica studies 131).

Huuhtanen, Pauli

Josefuksen kertomus Masadan joukkoitsemurhasta. [Josephus' story about the mass suicide at Massadah]. Teologisk tidskrift, 93 $1988,306-314$. 
JERVELL, Jacob

Diasporajødedommen og Jerusalems fall. [Diaspora Judaism and the fall of Jerusalem]. JuK II. Oslo 1986, 36-48.

728 Amoraitic period

see 662: TAMM

736 World War II and the Nazi Holocaust (1933-1945)

Beltzikoff, Boris

Ljuva trettiotal. [The wonderful thirties]. Svensk kyrkotidning, 83 1987, 427-430.

BÄSTLEIN, Klaus

Die Judenpogrome am 9./10. November 1938 in Schleswig-Holstein. Grenzfriedenshefte 1988, 163-190

Bästlein, Klaus

Das "Reichskommisariat Ostland" unter schleswig-holsteinischer Verwaltung und die Vernichtung der europäischen Juden. 50 Jahre nach den Judenpogromen. Reden zum 9./10. November 1988 in Schleswig-Holstein. Kiel, 1988, 65-85

Clausen, Lars

Die Probe der Verrohung. Die Juden in Schleswig-Holstein. (Schriftenreihe Gegenwartsfragen. 58) Kiel: Landeszentrale für Politische Bildung, 1988, 13-23

also in: 50 Jahre nach den Judenpogromen. Reden zum 9./10. November 1988 in SchleswigHolstein. Kiel, 1988, 6-17

ENGHOLM, Björn

Ansprache auf der Gedenkfeier in der Lübecker Synagoge am 8 . November 1988 zum 50 . Jahrestag der "Reichskristallnacht". 50 Jahre nach den Judenpogromen. Reden zum 9./10. November 1988 in Schleswig-Holstein. Kiel, 1988, 18-21

HaRCK, Ole

Krystalnatten i Sydslesvig : pogromen mod jøderne den 9.-10. november 1938. [The Crystal Night in Southern Slesvig]. Sønderjysk månedsskrift 1988, 307-317

PAUlinA-MürL, Linnea

Erinnerung und Verantwortung-Gedenken an den 9. November 1938. Die Juden in Schleswig-Holstein. (Schriftenreihe Gegen- wartsfragen. 58) Kiel: Landeszentrale für Politische Bildung, 1988, 7-12

Philipsen, Bernd

Der 9./10. November 1938 in Kappeln : die "Reichskristallnacht" in einer schleswigholsteinischen Kleinstadt. Grenzfriedenshefte. 1988, 153-162

\section{Wulf, Peter}

Die Verfolgung der schleswig-holsteinischen Juden im November 1938. Die Juden in Schleswig-Holstein. (Schriftenreihe Gegenwartsfragen. 58) Kiel: Landeszentrale für Politische Bildung, 1988, 25-38

also in: 50 Jahre nach den Judenpogromen. Reden zum 9./10. November 1988 in SchleswigHolstein. Kiel, 1988, 113-128

\section{History of the Jews post World War II}

KvaM, Ragnar

Helvetestransporten.[A hellish transport]. Oslo : J.W. Cappelens Forlag, 1986. 197pp.

\section{History of the Jews in Germany}

HARCK, Ole

Spuren der Juden in Schleswig, Holstein und Lübeck. Die Juden in Schleswig-Holstein. (Schriftenreihe Gegenwartsfragen. 58) Kiel: Landeszentrale für Politische Bildung, 1988, $39-59$

see 769: HARCK

\section{History of the Jews in Eastern Europe}

Heltberg, Kristine

De polske jøder. [The Jews of Poland]. Amol, 19-42

KrAG, Helen

Østjøder under østrigsk styre. [East European Jews under Austrian dominion]. Amol, $69-89$

Rasmussen, Knud \& RosenfeldT, Niels Erik

Jøderne og det russiske rige. [The Jews and the Russian Empire]. Amol, 45-65

ŚwIDERSKI, Bronisław

Det jødiske selvstyre i Polen. [Jewish autonomy in Poland]. Amol, 153-167 
Trautner-Kromann, Hanne

Religiøse bevægelser i østeuropæisk jødedom. [Religious movements in eastern European Jewry]. Amol, 113-126.

WARBURg, Margit

Amol iz geven. Amol, 9-15.

see 307: WARBURG

see 345: KUPCZYK-LEWIN

see 655: Schatz, Warburg

see 950: HAXEN

769 History of the Jews in the Scandinavian countries

\section{BLÜDNIKow, Bent}

Immigranter : Østeuropæiske jøder i København 1904-1920. [Immigrants : East European Jews in Copenhagen, 1904-1920]. JuN, 243-257.

Broberg, Gunnar

De judiska vānnerna : judiska bidrag till kulturlivet i sekelskiftets Sverige. [Jewish contributions to Swedish cultural life at the turn of the century]. $J u N, 223-241$.

Burstein, Marina

Den judiska befolkningen i Finland 18401975 : migrationsströmmar och bostadsmönster. [The Jewish population in Finland, 18401975 : patterns of migration and settlement]. $J u N, 127-151$.

\section{Christensen, Merete}

Jøderne i Danmark. [The Jews in Denmark]. $J u N, 27-38$.

HANSSON, Svante

Antisemitism, assimilation och judisk särart : svenskjudisk elitdebatt vid Hitlers maktovertagande 1933.[Anti-Semitism, assimilation, and the peculiar nature of Jews : discussion among Swedish intellectuals at the time of Hitler's takeover in 1933]. $J u N, 307-327$.

HaNsSon, Svante

Ett storverk om judarna i Norge. [A great work about the Jews in Norway]. $N J, 8(2)$ 1987, 167-169.

\section{HaRck, Ole}

Ausgewählte Quellen zur Geschichte der Juden in Schleswig-Holstein. Die Juden in Schleswig-Holstein. (Schriftenreihe Gegen- wartsfragen. 58) Kiel: Landeszentrale für Politische Bildung, 1988, 67-82

HaRCK, Ole

Julius Magnus-Ausstellung : zur Geschichte der jüdischen Gemeinden in SchleswigHolstein. Rendsburg : Senat der Stadt Rendsburg, 1985. 40pp.

HARCK, Ole

Jüdische Kleinstadtgemeinden in Schleswig-Holstein 1900-1938, erläutert am Beispiel Rendsburg. Grenzfriedenshefte 1988, 143-152 HARCK, Ole

Jüdisches Leben in Schleswig-Holstein : ein vergessenes Erbe. 50 Jahre nach den Judenpogromen. Reden zum 9./10. November 1988 in Schleswig-Holstein. Kiel, 1988, 39-55

HaRcK, Ole

Om jøderne i Rendsborg. Rendsborg/ Egernførde amt-Julen 1985. 1985, 1-16

HARCK, Ole

Übersicht über die jüdischen Gemeinden und Denkmäler in Schleswig-Holstein. Die Juden in Schleswig-Holstein. (Schriftenreihe Gegenwartsfragen. 58) Kiel: Landeszentrale für Politische Bildung, 1988, 63-66

Harviainen, Tapani

Judarna i Fintand. [The Jews in Finland]. JuN, 53-69.

\section{HARVIAINEN, Tapani}

Die Juden in Finnland. RelD, 8-26.

Harviainen, Tapani

Suomen juutalainen vähemmistö.

[The Jewish minority in Finland]. Juutalaisuus Helsingissä : näyttelyluettelo. Hki 1986, 9-20.

Johansen, Per Ole

Norsk Embedsverk og jødiske innvandrere og flyktinger 1914-1940. [The attitude of the Norwegian state bureaucracy towards Jewish immigrants and refugees, 1914-1940]. JuN, 287-306.

\section{Katz, Per B.}

De første jøder i Danmark. [The first Jews in Denmark]. JuN, 71-97.

KoBLIK, Steven

"Om vi teg, skulle stenarna ropa" : Sverige och judeproblemet 1933-1945. [Sweden and the Jewish problem 1933-1945]. Stockholm : Norstedts; 1987. -[Recension/review: 
Tommie Sjöberg, NJ, 9(1) 1988, 51-57].

LONNROTH, Erik

Europa, Norden och judarna. [Europe, Scandinavia and the Jews]. JuN, 9-14.

MENDELsoHn, Oskar 39-51.

Jødene i Norge. [Jews in Norway]. JuN,

\section{MENDELSOHN, Oskar}

Jødenes historie gjennom 300 år II. [Three hundred years of Jewish history]. Oslo : Universitetsforlaget, 1986. $664 \mathrm{pp}$.

NYMAN, Magnus

Judarna i Sverige 1775-1782 : pressdebatt och toleransbeslut. [Jews in Sweden 17751782 : press debate and decisions about increased tolerance. $J u N, 153-178$.

NYMAN, Magnus

Press mot friheten : opinionsbildning i de svenska tidningarna och åsiktsbrytningar om minoriteter 1772-1786. [The press against freedom : the development of public opinion in Swedish newspapers and the difference of opinion over minorities]. Uppsala : Uppsala universitet, 1988. 297 pp. (Acta Universitatis Upsaliensis. Studier $i$ idé- och lärdomshistoria 3). Diss.

\section{Pedersen, Sigfred}

Jøderne i Danmark. [The Jews in Denmark]. Presteforeningens blad, 77 1987, 657666 .

\section{ROHLÉN-WoHLGEMUTH, Hilde}

Många bäckar små : att vara flykting i Sverige under 30 -talet. [To be a refugee in Sweden in the thirties]. $N J, 8(1) 1987,64-71$.

RuNBLOM, Harald

Slutord. [Final remarks]. JuN, 355-360.

RüHMKORF, Eva

Ansprache anläßlich der Ausstellung "Isolation-Assimilation-Emanzipation" : zur Geschichte der Juden in Schleswig-Holstein 1584-1863. 50 Jahre nach den Judenpogromen. Reden zum 9./10. November 1988 in SchleswigHolstein. Kiel, 1988, 22-26

RÜHMKORF, Eva

Ansprache anläßlich der Eröffnung des Jüdischen Museums Rendsburg. 50 Jahre nach den Judenpogromen. Reden zum 9./10. November 1988 in Schleswig-Holstein. Kiel, 1988, 2733
TuCHEL, Johannes

"Jüdisches Museum Rendsburg" : Fragen zu seiner Konzeption und Umsetzung. $50 \mathrm{Ja}$ hre nach den Judenpogromen. Reden zum 9./ 10. November 1988 in Schleswig-Holstein Kiel, 1988, 34-38

TÄGIL, Sven

Judarna i Sverige. [The Jews in Sweden]. JuN, 15-25.

see 655: ILICKI, SCHATZ

see 662: JoHANNESSON, TYDÉN

see 672: FroselL

see 804: NARROWE

see 910: BÉLINKI

\section{Asian Jewry}

\section{WEster, Nils}

Bene Israel : a Jewish community in India. South Asian religion and society. Eds. Asko Parpola, Bent Smidt Hansen. London 1986, 205-222. (Studies on Asian topics 11).

\section{Individual biography}

\section{EITINGER, Leo}

Elie Wiesel-jøde-overlevende-menneske. [Elie Wiesel-Jew-survivor-man]. $N J$, 9(2) 1988, 99-107.

Hansson, Knut M. \& KaHan, Herman

Ilden og lyset. [The fire and the light]. Oslo: Cappelens, 1988. 205 pp.

HvidT, Kristian

Edvard og Georg Brandes opfattelse af deres jødiske herkomst. [Edvard and Georges Brandes' comprehension of their Jewish heritage]. $J u N$, 209-222.

SkJeraAsen, Magne

Lege for livet : en bok om Leo Eitingermedmennesket.[On Leo Eitinger]. Oslo : Cappelens, 1988. $263 \mathrm{pp}$.

see 727: BILDE

\section{History of Zionism}

Hansson, Svante

Myten som vapen : antisemitism, antisionism-tva folks dröm om ett land. [The myth as weapon : anti-Semitism, anti-Zionism-two 
peoples' dream of a country]. Stockholm : Askelin \& Hägglund, 1986. $87 \mathrm{pp}$.

NARROWE, Morton H.

Jidische Volkschtime (Sic). NJ. 7(2), 1986, 92-103

see 921: Fruitman

921 General Jewish periodicals (newspapers and magazines)

Fruitman, Stephen

Cultural Zionism in Sweden : Daniel Brick's Judisk Krönika. NJ, 9(2) 1988, 108130.

see 804: NARROWE

827 Zionist revival to the creation of the State of Israel

see 737: KVAM

910 General collections of essays on Jewish topics

BÉLINKI, Karmela

Tikva-hopp. [Tikvah-hope]. Otalampi

: Sahlgrens förlag, 1987.

950 Jewish bibliography

BoLL, Jens Kristian Lindhart
Mystik $i$ islam och jødedom : en kommenteret bibliografi.[Mysticism in Islam and Judaism : an annotated bibliography]. Århus : Jens Kristian Lindhart Boll, 1986. 120 pp.

DAHLA, Björn

Bibliography of Nordic research in comparative religion 1984-1985. Temenos, 22 (1986) 1987, 169-228.

Harck; Ole \& Wulf, Peter

Auswahlbibliographie. [Selected bibliography on the history of the Jews in SchleswigHolstein]. Die Juden in Schleswig-Holstein. (Schriftenreihe Gegenwartsfragen. 58) Kiel: Landeszentrale für Politische Bildung, 1988, 83-87

HAXEN, Ulf

Liste over litteratur om jøderne i Østeuropa. [A list of literature about the Jews of Eastern Europe]. Amol, 193-211

ROHLÉN-WOHLGEMUTH, Hilde

Svensk judisk bibliografi 1983-1985. [A Swedish Jewish bibliography 1983-1985]. NJ, 7(2) 1986, 124-130.

ROHLÉN-WOHLGEMUTH, Hilde

Svensk-judisk bibliografi II : facklitteratur 1977-1986 : skönlitteratur 1977-1986. [A Swedish Jewish bibliography : non-fiction 1977-1986 : fiction 1977-1986]. Stockholm : Hillelförlaget, 1987. 82 pp. (Skrifter utgivna av sällskapet för judaistisk forskning 6). 